Pécsi Tudományegyetem - Közgazdaságtudományi Kar Regionális Politika és Gazdaságtan Doktori Iskola Pécs

\title{
MIERT NEM ELEG ADAPTIV A MAI ERP RENDSZER? AZ INTEGRÁLT VÁLLALATIRÁNYíTÁSI RENDSZEREK VIZSGÁLATA A KKV-K ÉS A NAGYVÁLLALATOK SZEMSZÖGÉBÖL
}

Abszolutóriumi dolgozat - Review

2013

Szerző: Nagy Viktor

Ph.D. hallgató nviktore@gmail.com

Pécsi Tudományegyetem

Közgazdaságtudományi Kar

Regionális politika és gazdaságtan doktori iskola

Konzulens: Dr.Dobay Péter 


\section{BEVEZETÉS}

Az információ technológia fejlődésével párhuzamosan a hozzá használt eszközök, szoftverek is kiapadhatatlan tárházat kínálnak a felhasználók számára. Ez különösen igaz a gazdasági élet szereplőire, akik folyamatos versenyben állnak egymással és törekszenek nem csak a már megszerzett piaci pozíciójuk megtartására, de az újabb és újabb területek meghódítására is, amihez elengedhetetlen az előnyszerzés a vetélytársakkal szemben. A piaci előny megszerzéséhez azonban minden olyan információnak, adatnak és tudásnak a birtokában kell lenni, amelyekkel ez elérhető, egyébként életbe lép Lord Raleigh örökérvényü mondata „Az információ drága: csak a hiánya kerül többe."

Azt sem szabad azonban elfelejteni, hogy a maga a tudás és az információk, adatok halmaza, még nem helyez egyetlen gazdasági társaságot sem előnyösebb pozícióba a többiekhez képest. Ahhoz hogy mindebből előnyt kovácsoljon egy adott szervezet, az első feladat, a szelekció elvégzése. Ezt követően az értékes adatokat, információkat - amelyek segítik a vállalkozás érvényesítését, ambícióit - rendezni szükséges, amihez elengedhetetlen egy olyan rendszer, amely nem csak rendszerezi a halmazban lévő adatokat, de össze is gyüjti, mind a vállalat belső, mind pedig külső környezetéből.

Ma már számtalan olyan rendszerrel találkozunk a piacon, amelyek mind megfelelnek annak az elvárásnak, hogy az adatokat és információkat összegyüjtsék és rendszerezzék. Ezek a rendszerek azonban egy sémára készülnek, van, amelyik többet nyújt, van, amelyik egy kicsivel kevesebbet, de felépítésben szinte nincs különbség, mivel egy standard vállalati folyamatra épülnek. A gazdaság szereplői azonban eltérő méretűek és gazdasági rendszerüek, amiből egyenesen következik, hogy folyamataik is kisebb, nagyobb mértékben, de eltérnek egymáséitól, vagyis egy standard folyamatokra épülő rendszer nem tudja maradéktalanul kielégíteni igényeiket és nem képes olyan rugalmasan igazodni a vállalkozást érintő változásokhoz, mint ahogy maga a vállalkozás reagál a megváltozott gazdasági helyzetekre.

Jelen tanulmány célja vizsgálni a piacon meglévő ERP rendszerek adaptív viselkedését az üzleti folyamatok változásának tekintetében egy részről az integrált vállalatirányítási rendszerek tulajdonságainak, másrészről a gazdasági életben résztvevő felhasználók igényeinek szemszögéből. Hiszen más az igénye és elvárása egy KKV-nak vagy egy mikro vállalkozásnak, mint egy nagy- vagy multinacionális vállalatnak. Azonban minden gazdasági szereplőnek fontos, hogy minél hatékonyabbá tegye vállalkozása folyamatait, azt pedig minél költséghatékonyabban tegye meg. Valamint az is nagyon fontos, hogy az 
üzleti élet változásait minél rugalmasabban tudják, minél rövidebb idő alatt lereagálni, és ez nem csak a vállalakozásra, hanem az eszközeire is igaznak kell lennie, természetesen minimális erőforrások felhasználásával.

A kutatásom során két szakaszt választottam külön, az első szakaszban a piacon lévő ERP rendszereket és azok adaptív jellemzőit, tulajdonságait vizsgálom SWOT analízis segítségével. Míg a második szakaszban az összegyüjtött információk alapján SWOT analízis segítségével elemzem a különböző méretű szervezetek jellemzőit és igényeiket az integrált vállalatirányítási rendszerrel kapcsolatosan. Ugyanebben a szakaszban fogom összehasonlítani a KKV-k és a nagyvállalatok igényeit, megvizsgálni a különbségeket és hasonlóságokat és azok okait.

Vizsgált hipotéziseim a következő:

H1: A folyamatos piaci változás követéséhez, a jelenlegi verseny eszköztár nem elég adaptív.

H2: A gazdasági élet szereplőinek mérete, formái és folyamatai meghatározzák rugalmasságukat az üzleti élet változásaival szemben.

H3: A gazdasági élet szereplőinek mérete, formái és folyamatai befolyásolják a használt ERP rendszer alkalmazkodását a megváltozott piaci helyzetekhez.

Az eredmények összegzése mellett következtetéseim és javaslataim is helyet kapnak dolgozatomban, amelyekre a kutatási eredményeim szolgálnak alapul. A dolgozat zárásaként, mind a szakirodalmi, mind a gyakorlati kutatás fontosabb tanulságait szeretném kihangsúlyozni, amellett, hogy összefoglalom a dolgozatban elhangzottakat. Valamint néhány olyan gondolatot is szeretnék megosztani az olvasóval, amelyek a későbbiek folyamán hasznosak lehetnek, akár a kutatásban szereplő vállalatok, akár azon gazdasági társaságok számára, akik még az ERP rendszerek bevezetése, használata előtt állnak.

\section{A kutatás célja, elözményei, fóbb kérdései}

A mai gazdasági helyzetben a vállalkozások egyre nagyobb hangsúlyt fektetnek arra, hogy minél több olyan eszközzel rendelkeznek, amelyek segítségével megőrizhetik, illetve növelhetik piaci részesedésüket. Ezek között vannak marketing eszközök, a gazdasági társaságok erőforrásait befolyásoló eszközök, és természetesen a vállalkozás üzleti 
stratégiája szempontjából fontos és nélkülözhetetlen adatok és információk akkumulálására és feldolgozására használható eszközök.

A dolgozat célja megvizsgálni ez utóbbiak közül a jelenleg piacon lévő és majdan a piacra kerülő ERP rendszerek adaptivitását. Ezt az adaptivitást egyrészről az ERP rendszerekben meglévő hiányosságok, másrészről a felhasználói oldal részéről megjelenő igények alapján vizsgálom, hiszen ezek befolyásolják egy vállalatirányítási rendszer alkalmazkodóképességét.

A kutatás során elemzem a piacon jelenleg megtalálható integrált vállalatirányítási rendszereket tulajdonságaik, funkcióik alapján. Ezen felül számba veszem a különböző méretű gazdasági társaságok igényeit a használni kívánt, vagy már működő információs rendszerekkel kapcsolatosan.

A téma aktualitását az adja, hogy jelenleg számos vállalatirányítási rendszer megoldás közül válogathatnak a gazdasági társaságok, sokszor előfordul azonban, hogy nem a megfelelő rendszert választják ki a döntéshozók, és az nem, vagy csak részben felel meg a vállalkozás igényeinek. Amiből egyenesen következik, hogy az alkalmazott ERP rendszer még kis mértékben sem lesz képes lekövetni az adott piac és vállalkozás folyamatainak változását. Ebből pedig inkább hátránya, mint előnye származik az adott gazdasági társaságnak. A vállalat igényein felül, a használni kívánt vállalatirányítási rendszer tulajdonságai és támogatási opciói is befolyásolják az adott rendszer adaptivitását. Ugyanakkor ebből nem következik egyenesen, hogy a „legnépszerübb”4 rendszer a legmegfelelőbb a vállalkozás számára, és hogy később ez az ERP képes lesz a folyamatok változásait megfelelően kezelni, anélkül hogy gazdasági hátrányt okozna.

Dolgozatomban a következő kérdésekkel foglalkozom:

- Mennyire tudják a piacon lévő információs rendszerek követni a folyamatos piaci változásokat?

- Mennyire rugalmasak az üzleti élet változásaival szemben a gazdasági élet szereplöi?

- Befolyásolja-e ezt a gazdasági társaság mérete, formái és folyamatai?

- Milyen információs rendszer leírások szerepelnek a szakirodalomban?

- Azok mennyire találkoznak a meglévő ERP rendszerek felépítésével?

\footnotetext{
${ }^{4}$ A legnépszerübb alatt azt az ERP rendszert értem, amelyet a legtöbb vállalkozás alkalmaz. Ezek többnyire nemzetközileg ismert rendszerek, és nem feltétlenül az adott ország ERP rendszerekkel foglalkozó vállalkozásainak fejlesztései.
} 
- Melyek a leggyakrabban említett igények az információs rendszerrel kapcsolatosan, amelyek a vállalkozások részéről megfogalmazódnak?

- Hogyan lehetne a gazdasági társaság folyamatait és az ERP rendszereket a leghatékonyabban összekoordinálni?

A dolgozatban tárgyalt kutatási kérdésekhez tartozó részfeladatok:

1. Nemzetközi, magyarországi és saját tapasztalatok, statisztikák, esettanulmányok és a kapcsolódó szakirodalom eredményeit összegzem és elemzem az ERP rendszerek és a vállalkozások folyamatainak kapcsolatában. Ebben a részfeladatban mutatom be az integrált vállalatirányítási rendszert, egy vállalkozás általános folyamatait és a hozzájuk kapcsolódó teendőket, valamint néhány ismert ERP rendszert. Ezzel igazolva a téma és a megközelítés létjogosultságát.

2. Ebben a részfeladatban foglalkozom a vállalkozások folyamatai és az ERP rendszerek közötti kapcsolattal, hogy milyen formálódásokra van szükség a megfelelő kohézió létrehozására. Ez a vizsgálat kiterjed arra is, hogy mekkora rugalmasság van a jelenlegi információs rendszerekben, amely még alkalmazkodni tud különösebb gond nélkül a gazdasági és így a folyamatváltozásokhoz.

3. Központi kutatási kérdésem az informatikai rendszerek alkalmazkodóképessége, hogy a standard folyamatokra épülő rendszerek hogyan képesek különösebb külső beavatkozás nélkül követni a folyamatváltozásokat. Milyen megoldások léteznek az információs rendszer és a vállalkozási folyamatok közötti szimbiózis megteremtéséhez. További vizsgálati kérdéseim inkább gyakorlati jellegűek. Melyek azok az igények a felhasználók részéről, amelyekre befolyással vannak a piaci változások, és ezáltal meghatározzák a folyamat változások amplitúdóját, melyet az információs rendszereknek le kell követniük különösebb probléma nélkül? A jelenlegi informatikai megoldások milyen mértékben elégítik ezt ki? A kutatási kérdések igazolására a vizsgált meglévő rendszerek közül megnevezem azokat, amelyek fejlesztéssel adaptívabbá tehetőek a gyakorlatban.

\section{A kutatás módszere}

A meghatározott kutatási feladat az informatika és a gazdaságtudomány területéhez tartozik, és ez meghatározza a használni kívánt módszertant. Kutatásom elvégzésére kvalitatív módszerek alkalmazhatók. 
Kutatásom során a vizsgálati cél meghatározására a Yin (1994) féle kategória megkülönböztetéseket használom, amely leíró, felfedező és magyarázó. Ebből a szempontból vizsgálatom leíró és feltáró jellegű is egyben. Leíró, mert a dolgozat első részében a hipotézis vizsgálathoz nélkülözhetetlen szakirodalmat mutatom be és kategorizálom. Feltáró jellegű is, hiszen a hipotézis vizsgálathoz esettanulmány elemzést, és kérdőíves megkeresés elemzést is alkalmazok. A Yin féle kategóriákhoz tartozó kutatási stratégiák a következőek:

- kísérleten alapuló

- kérdőíves felmérésen alapuló

- másodlagos elemzésen alapuló

- történeti elemezésen alapuló

- esettanulmány elemzésén alapuló

A felsorolt stratégiák közül jelen kutatásban a kérdőíves felmérésen, a másodlagos elemzésen és az esettanulmány elemzésen alapuló stratégiákat fogom alkalmazni, mert úgy vélem ezeknek a módszereknek a segítségével tudom tényszerủen igazolni a hipotéziseimet. A módszerek kiválasztásánál elsődleges szempont volt, hogy minél nagyobb mintából tudjak dolgozni, hiszen az ERP rendszerek alkalmazkodóképességét csak így tudom hitelt érdemlően tanulmányozni, elemezni.

H1: A folyamatos piaci változás lekövetéséhez a jelenlegi verseny eszköztár nem elég adaptív.

Az első hipotézis esetében a vizsgálataimat a szakirodalom felől közelítem meg. Itt tisztázok le olyan fogalmakat, mint adaptív, piaci változások, verseny eszköztár. Ennek a hipotézisnek az igazolására esettanulmány elemzést kívánok használni, amelyek azt hivatottak bemutatni, hogy egy-egy hirtelen jött piaci változást a vállalati folyamatok és az ERP rendszer időben mennyire tud lekövetni, milyen reakció és átfutási idővel.

H2: A gazdasági élet szereplőinek mérete, formái és folyamatai meghatározzák rugalmasságukat az üzleti élet változásaival szemben.

Második hipotézisemet a felelhető szakirodalmi értekezések és tanulmányok eredményeinek elemzése alapján kívánom alátámasztani. Ebben az esetben úgy vélem, a szakirodalom feldolgozása után elég bizonyítékot nyerek a felvetésem igazolására.

H3: A gazdasági élet szereplőinek mérete, formái és folyamatai befolyásolják a használt ERP rendszer alkalmazkodását a megváltozott piaci helyzetekhez. 
Utolsó feltételezésem igazolására, a vállalkozások igényeinek és az ERP rendszerek funkció kínálatának összehasonlítását tartom célszerünek, így a szakirodalom mellett összegyüjtött tapasztalati információk elemzésének eredményeit használom fel.

\section{A kutatás során használt fogalmak magyarázata}

Úgy vélem, hogy mielőtt belekezdenék az ERP rendszerek adaptivitásának kutatásába, mindenképpen szükséges néhány, a vizsgálat során gyakran előforduló fogalom tisztázása, értelmezése, hogy az olvasó számára is világos legyen, milyen értelemben használom az adott fogalmat. Ez azért is célszerü, mert a későbbiek folyamán a kutatás alanyai is különbségeket tudnak a tenni fogalmak között, és ezek értelmében tudják válaszaikat kérdéseimre megadni, így biztosak lehetünk abban, hogy a kutatás eredményei megfelelőek és hitelesek lesznek. A fogalmak tisztázását fontosnak tartom továbbá - még a kutatás megkezdése előtt -, abból a szempontból is, hogy a vizsgálatok előrehaladtával fogalom értelmezési problémák ne nehezítsék a kutatás eredményeinek gyüjtését és értékelését.

Az adaptív latin eredetű szó és alkalmazkodót jelent. Az élet és a technika bármely területét nézve sok mindenre mondhatjuk, hogy adaptív, vagy, hogy nem az. Az adaptív rendszerek képesek alkalmazkodni a környezeti változásokhoz, a kérdés ebben az esetben csak az, hogy mennyire gyorsan és pontosan, ezzel szemben a nem adaptív rendszerek nem reagálnak a környezet okozta változásokra. Jelen tanulmány szempontjából az adaptív egy meghatározó kifejezés, mivel azt kutatom, hogy a környezeti változások ebben az esetben az gazdasági élet változásai - mennyire váltanak ki alkalmazkodó magatartást a vállalatirányítást segítő informatikai rendszerekből.

A vállalatirányítási rendszert (VIR), mint fogalmat kétféle értelemben használjuk, az egyik az informatikai értelmezés, amikor magáról az ERP rendszerekről beszélünk. A másik értelmezés pedig, amikor a gazdasági társaság számviteli törvény és minőségbiztosítási előírások által meghatározott folyamatainak összességéről beszélünk. Míg utóbbi értelmezés a vállalkozás müködésének alapjait határozza meg, addig az első ennek hatékonyságát befolyásolja. Kutatásomban a vállalatirányítási rendszer megnevezést a második értelmezés szerint fogom használni, míg az ERP rendszer esetében az informatikai rendszer és az informatikai támogató rendszer kifejezéseket fogom még használni. 
Az integrált rendszer, egy olyan informatikai megoldás, amely adatmegosztás révén képes egységes rendszert alkotni, anélkül, hogy ez a rendszer felhasználóit akadályozná munkájuk elvégzésében, vagy akár csak észrevennék az adatmegosztást. (T.F. Wallace M.H. Kremzar 2006)

\section{Az Integrált információs - informatikai rendszerek}

Az integrált információs - informatikai rendszerek ugyanazt a kettősséget takarják, melyet már a vállalatirányítási rendszer fogalmának értelmezésekor is felvetettem, hiszen ez a rendszer magában foglalja az információ gyüjtését, továbbítását és számítógépes terjesztését is (Orbán 2006). Ezek a rendszerek moduláris felépítésủek általában, és a meghatározott feladatcsoportokat - amelyeket gazdasági szempontok határoznak meg önálló részegységek segítik a teendők elvégzésében. (Orbán 2006)

Az ERP rendszerek hatalmas fejlődésen mentek keresztül az elmúlt évtizedekben, a kezdeti vállalati erőforrás tervezéstől eljutottunk egy sokkal komplexebb és globálisabb informatikai rendszerhez, mely segíti a vállalatot, vállalatcsoportot üzleti stratégiájának megvalósításában. Az ERP rendszer fő feladata előre jelezni és összeegyeztetni a keresletet és a kereslet-kielégítés menetét. Egy olyan eszközrendszer, melynek segítségével az egész vállalat gazdasági folyamataira lehet előrejelzést, tervezést, ütemezést megvalósítani. Valamint lehetőséget biztosít arra, hogy létrehozzunk egy teljes ellátási láncot, amelybe a szállítókat és a vevőket is bekapcsolhatjuk. A rendszer segítségével kapcsolatot létesíthetünk az értékesítés, a marketing, a termelés, a termékfejlesztés, a logisztika, a beszerzés, a pénzügy és az emberi erőforrás között. A jól működő ERP segíti a vállalat vezetöinek döntéshozatalát. (T.F. Wallace - M.H. Kremzar 2006)

\section{1. ábra. ERP rendszerek fejlődése}

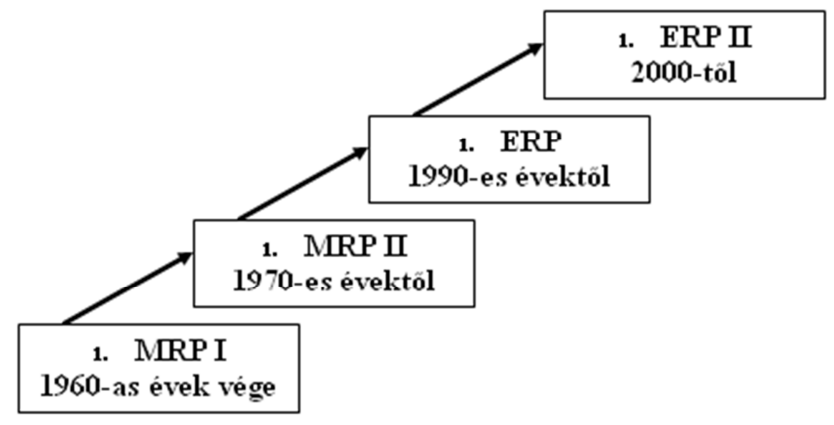

Forrás: Dr. Holyinka Péter: Az információs rendszerek rövid fejlödés története. http://www.erport.hu/index.php?id=44 / Kelemenné Ternai Katalin (2003): Az ERP rendszerek metamorfózisa In: Vezetéstudomány 2003. július - augusztus 
Természetesen az ERP rendszer mai formájának elérése egy hosszú folyamat végeredménye és változó, meg-megújuló gazdasági folyamatok következménye. Ahhoz, hogy az anyagigény tervezéstől eljussunk az ellátási lánc menedzsmenthez az kellett, hogy a gazdasági társaságok felismerjék annak az előnyét, hogy egyetlen komplex rendszerben kezelik saját gazdasági folyamataikat a kezdetektől (a vevői megrendeléstől) a végéig (az áru/szolgáltatás kiszállításáig, vevőhöz juttatásáig). Ebbe a komplex rendszerbe pedig már a vállalat több területét is bele kellett vonni, valamint a vevőket és szállítókat is, és egyszer csak a belső rendszerből egy globális, integrált rendszer lett. Az ERP rendszer esetében egy az egész vállalkozást átfogó rendszerről beszélünk - mint, ahogy azt Wallace és Kremzar definíciójában az előzőekben láthattuk -, amely a meglévő vállalati folyamatokat teszi hatékonnyá, ugyanakkor nem szabad csak a szoftverre helyezni a hangsúlyt, hiszen a komplex rendszer áll az informatikai támogató rendszerből és a vállalati folyamatokat összefogó vállalatirányítási rendszerből. Ezt követve a nemzetközi szakirodalom, már inkább a rendszert teljesebb módon leíró Enterprise System (ES), vagy Integrated Enterprise Application (IEA) kifejezést használja.

\subsection{Az ERP rendszer elönyei}

A vállalatirányítási szoftverek fejlődése lehetővé tette, hogy minden vállalati tranzakció egy adatbázisba fusson be, amely egy megfelelő egységes rendszer segítségével érhető el. Az ERP rendszerek kialakulásával a menedzsment óriási információs bázishoz jutott, folyamatosan bővülő funkcionalitásukkal ezek a rendszerek jelentik ma a vállalatok informatikai támogatásának az alapját. Elősegíti a döntéshozatali folyamatokat. Integrációt biztosít az értékesítés, a marketing, a gyártás, az üzemeltetés, a logisztika, a vásárlás, a finanszírozás, az újtermékek fejlesztése, a humán-erőforrás számára. Ezzel lehetővé teszi, hogy az alkalmazottak magasabb színvonalon végezhessék a munkájukat, alacsonyabb költségek és árukészlet mellett. (T.F. Wallace - M.H. Kremzar 2006)

A modulokból felépülő programcsomag bevezetése elsősorban rendet visz a cég életébe. Segítségével a döntéshozók minden pillanatban tisztán láthatják vállalkozásuk pozícióját, szükség esetén bármikor be tudnak avatkozni.

A rendszer bevezetése racionalizálja a működést, időmegtakarítást eredményez, és növeli a hatékonyságot. Ha az alkalmazottak kevesebb időt töltenek el papírmunkával, több idejük marad más feladatokra.

Az ERP rendszerek előnyei (T.F. Wallace - M.H. Kremzar 2006): 
- a vállalati tevékenység realizálásához és menedzseléséhez hatékony segítségnyújtás

- a szervezet müködési költségeinek csökkentése

- a belső integráció, az információáramlás, együttmüködés javítása

- jobb döntések és magasabb színvonalú szervezeti teljesítmények elérésének támogatása

- segít a vevői kör elégedettebbé tételében és a vállalati eredményességben

- standard szoftverek, vagyis bármikor elérhetőek, és nem kell a vállalkozásnak a fejlesztésekre várnia

- elérhetővé teszi a vállalkozás alkalmazottai számára a vállalati információk, tudásbázis gyors elérését

- javuló munkafegyelem, és termelékenység

- bizonylati fegyelem betartásának javulása

- a vállalat vezetőségének több lehetősége adódik az ellenőrzés és a számon kérésére

- redundancia-mentes adatbázis kialakulása

A felsoroltak biztosítják a szervezet tanulását, környezetének változásához való alkalmazkodását, az információáramlást, és a hatékony értékteremtéshez szükséges módszereket. Manapság egy jól szervezett, bevezetett és müködtetett ERP rendszer olyan eszköz egy vállalkozás kezében, mellyel nem csak folyamatait teheti hatékonnyá, hanem jelentős versenyelőnyre is szert tehet, az ebben a rendszerben tárolt adatok információként való felhasználásával.

\subsection{Az ERP rendszer hátrányai}

Az ERP rendszer felhasználóit elbizonytalaníthatja az új rendszer, hiszen nem ismerik annyira, mint az eddig használt rendszereket, informatikai eszközöket. Habár egyszeres adatbevitel történik, általában jóval több adatot rögzítenek az adott informatikai rendszerbe, ami hibázási lehetőségeket rejt magában.

Az új informatikai rendszer és az ezzel együtt járó új információk megváltoztathatják az adott gazdasági társaság belső rendszerét, folyamatait. Az ERP rendszer számos folyamatot képes automatizálni, aminek következménye, hogy a vállalkozáson belül egyes adminisztratív tevékenységek feleslegessé válnak, és az ezeken dolgozó alkalmazottakkal valamit kell kezdenie a vállalkozásnak, ami többlet költséget eredményezhet. 
Az ERP rendszer bevezetése és üzemeltetése önmagában is plusz költséggel jár, amelyeket a vállalkozás nem minden esetben képes egyben és önerőből megfinanszírozni. A bevezetéskor az alapköltségeken felül, azonban, olyan egyéb költségek is megjelenhetnek, mint például az alkalmazottak oktatása, a kulcsfelhasználók kiválasztása, felkészítése, amelyek a rendszer müködtetésében nyújtanak segítséget a munkatársak számára. Ezenfelül a rendszert a vállalathoz kell igazítani, felül kell vizsgálni a vállalkozás folyamatait, mik azok, melyeket az informatikai rendszerhez kell igazítani és melyek azok, amelyekhez az ERP rendszert kell idomítani. (T.F. Wallace - M.H. Kremzar 2006)

Az ERP bevezetésével kapcsolatos problémák (Dr. Schwarczenberg 2008; Wilcocks 2003; Summer 2003):

- Teljesíthetetlen idő és költségterv. Ebben az esetben a vállalatnak pontosan tudnia kell, hogy az általa kiválasztott ERP rendszernek a bevezetése mennyi időbe telik a vállalkozás szempontjából. A bevezetésre szánt időkeretet a gazdasági társaságok rendre túllépik, így költségeik is ezzel arányosan növekednek. Az informatikai rendszer bevezetése amúgy is hatalmas költségekkel jár. A költségek három csoportba sorolhatóak: számítástechnikai, emberi erőforráshoz kapcsolódó, és a rendszerhez szükséges adatokhoz (konvertáláshoz) kapcsolódó költségek.

- Szervezetlenség: a projektcsapat, illetve az informatikai projekt vezetéséhez szükséges tapasztalatok hiánya, akik bevezetnék a kiválasztott ERP rendszert;

- A változástól való félelem ${ }^{5}$

- Nincsenek egyértelmüen megfogalmazva a rendszerrel kapcsolatos elvárások

- Az üzleti folyamatok áttekintésének, racionalizálásának hiánya ${ }^{6}$

- Irreális elvárások a rendszerrel kapcsolatban

- A vezetői és felhasználói elkötelezettség hiánya a rendszer iránt

- Kulcsfelhasználók túlterheltsége

- Nem megfelelő rendszeroktatás

- Korábbi, átvett adatbázisok rendezetlensége

\footnotetext{
${ }^{5}$ A változás menedzseléséről a későbbiek folyamán bővebben lesz szó.

${ }^{6}$ Mint azt az előzőekben említettem, vannak olyan folyamatok, melyekhez és vannak olyanok amelyeket az ERP rendszerhez kell igazítani, ehhez pedig át kell gondolni ezeket a folyamatokat.
} 
Mindnet egybevetve sokkal több érv szól egy ERP rendszer bevezetése mellett, mint ellene. Ellenérvként jobbára a bevezetéskor felmerülő problémákat lehet felvetni, amelyek kiküszöbölhetőek, ha a rendszer kiválasztása előtt a vállalkozás pontosan megfogalmazza, hogy mire szándékozik használni a rendszert és mit kíván elérni annak használatával. Ennek hiánya a leggyakoribb hiba, amit egy adott rendszer bevezetésekor a szervezetek elkövetnek. ${ }^{7}$

\subsection{A vállalatirányítási információs rendszer felépítése}

A kutatott terület szempontjából fontos megvizsgálni a mai ERP rendszerek, és az ezeket megelőző, korábbi információs rendszerek közötti kötödéseket, kapcsolatokat. Hogyan épülnek egymásra, és miként teremtenek kapcsolatot a vállalkozás működési szintjeivel?

\section{1. táblázat. A vállalat múködési szintjeit támogató információs rendszerek}

\begin{tabular}{|c|c|c|c|c|}
\hline & $\begin{array}{c}\text { Vezetői } \\
\text { Oöntések }\end{array}$ & $\begin{array}{c}\text { Vevőkapcsolat menedzsment } \\
\text { (CRM) } \\
\text { Információs } \\
\text { rendszer } \\
\text { (MIS) }\end{array}$ & $\begin{array}{c}\text { Beszállítói kapcsolatkezelő } \\
\text { rendszer (SRM) } \\
\text { Ellátási lánc kezelő rendszer } \\
\text { (SCM) }\end{array}$ & $\begin{array}{c}\text { Vállalati } \\
\text { teljesítmény- } \\
\text { menedzsment } \\
\text { rendszer (EPM) }\end{array}$
\end{tabular}

Forrás: Kacsukné Dr. Bruckner Lívia - Kiss Tamás (2007): Bevezetés az üzleti informatikába 121. oldal

A felvázolt vállalatirányítási informatikai rendszerben a tranzakciófeldolgozórendszereken alapulnak a vezetői információs rendszerek, a gyártást támogató, és a döntéstámogató rendszerek. Ezekből, az operatív és műveletvégzés rendszerekből épül fel maga az ERP rendszer.

\subsection{A vállalati teljesítmény növelése ERP - vel}

Az integrált informatikai rendszerek bevezetése és használata számos előnyt jelent a gazdasági társaságok részére az úgynevezett „hagyományos” = nem integrált vagy elszigetelt megoldásokkal szemben. Azok a vállalkozások, akik integrált informatikai

\footnotetext{
${ }^{7}$ A későbbiek folyamán szó lesz a rendszer bevezetés ,,arany” szabályairól
} 
rendszert használnak lényegesen több információhoz, adathoz jutnak hozzá, amelyeket később másformában, de hasznosítani tudnak. A többlet információn túl, az adatgyüjtés metódusa is sokkal egyszerübbé válik számukra, mert egy ilyen integrált informatikai rendszerben a szervezet minden részlege ugyanazokkal az információkkal rendelkezik és mindegyik a saját jogosultsága által tudja frissíteni azokat.

$\mathrm{Az}$ úgynevezett hagyományos folyamatok egyáltalán nem voltak hatékonyak, de végrehajthatóságuk egyszerüsége vonzotta a vállalkozásokat. Ebben az esetben minden részleg elvégezte a maga feladatát, ha pedig tévedés történt, akkor mindig a külsős volt a hibás. Integrált vállalatirányítási rendszer esetén a felelősség már nem hárítható át, itt mindenki felelős az adatok és információk pontosságáért, ráadásul a feldolgozás azonnali. (T.F. Wallace - M.H. Kremzar 2006)

Sajnálatos módon az emberek, különösen a munkában félnek a változásoktól, az ERP rendszer bevezetésével és használatával azonban módosítaniuk, újítaniuk kell munkafolyamataikon. Amennyiben egy gazdasági társaság ilyen integrált informatikai rendszert tervez bevezetni, akkor az első feladat azon célok meghatározása, melyeket az informatikai rendszer segítségével el kíván érni. Tisztáznia szükséges saját folyamatait és azok a vállalat környezetére gyakorolt hatásait. El kell döntenie, melyek azok a munkamódszerek és üzleti folyamatok, amelyeket az informatikai rendszerhez kíván igazítani, és melyek azok melyekhez a rendszert kell igazítani. Ezek nélkül a lépések nélkül bevezetett ERP rendszer nem hogy produktívabbá tenné a vállalkozás folyamatait, de könnyen lelassíthatja a vállalat tevékenységét. Hiszen az eszközök megszerzése önmagában még nem jelenti azt, hogy kezelni is tudjuk őket, már pedig ha nem tudják használni, akkor versenyelőnyhöz sem juttatnak. A versenyelőny megszerzéséhez, az eszközökön túl, azok használatának és tovább fejlesztésének tudása is szükséges.

Sok vállalatvezető gondolja úgy, hogy egy szoftverváltással már nagy eredményeket érhetnek el, de a valóságban a vállalatirányítási rendszer csupán nagyobb mennyiségü információt tud gyorsabban és alacsonyabb szintekre eljuttatni. Ha az egyes munkafolyamatok nem változnak, akkor rossz információ áramlik veszélyes gyorsasággal a vállalaton belül. (T.F. Wallace - M.H. Kremzar 2006)

\section{Megfogalmazott igények és elérhető funkciók}

Ahhoz, hogy tiszta képet kapjunk a vállalatirányítási informatikai rendszer adaptivitásáról, fel kell mérni, a gazdasági társaságok ERP rendszerekkel kapcsolatos elvárásait, igényeit 
és az ERP rendszerek által kínált lehetőségeket, mert tudnunk kell, hogy az igények és az elérhető funkciók mennyiben fedik és mennyiben állnak távol egymástól.

Az összehasonlításból következtetni lehet a vállalatirányítási és az informatikai rendszerek rugalmasságára, láthatóvá válik, hogy mennyire képesek ezek a rendszerek lekövetni a piaci változásokat anélkül, hogy fennakadást, vagy üzleti hátrányt okoznának a szervezet számára. A müködéshez szükséges a különböző rendszerek - vállalatirányítási rendszer, támogató informatikai rendszer - összehangolása, melynek eredményeként később létre jöhet a VIR.

Összefoglalva a nagy szervezetek információ igénye a következő:

- A vállalati folyamatok során keletkezett adatok rögzítése

- A vállalati folyamatok során keletkezett adatok alapján meghatározott mérőszámok számolása és rögzítése

- A vállalat környezetében a vállalkozásra hatással lévő tevékenységek során létrejött adatok rögzítése

- Számviteli adatok rögzítése és riportálása a jogszabályban megfogalmazottak alapján

- Költségek nemenként, személyenként, kódonként való rögzítése és riportálása, elemzése

- Pénzügyi tevékenységekkel kapcsolatos adatok, információk, bizonylatok rögzítése, létrehozása

- Anyagfelhasználások rögzítése, fogyás jelentések készítése, elemzése

- A vállalkozás ügyfél és partner adatainak gyüjtése, rögzítése és szeparálása

- Termékfejlesztéssel kapcsolatos adatok gyüjtése, rögzítése, elemzése

- Marketinggel kapcsolatos tevékenységek adatainak rögzítése, elemzése

- Stratégiai (értékesítési, marketing, termelés, stb) tervek és tények rögzítése és elemzése

- Minőségirányítási rendszerrel kapcsolatos mérőszámok, adatok rögzítése és elemzése

- Leányvállalatok és kapcsolódó vállalkozások adatainak és információinak gyüjtése, rögzítése és integrálása a szervezet információs rendszerébe

- A vállalkozás teljesítmény értékeléséhez szükséges adatok gyüjtése, rögzítése és értékelése

- A szervezeten belüli részlegek tevékenységének adatformájú rögzítése 
- Szervezetfejlesztéshez szükséges információk gyüjtése

A kisebb szervezetek információs igénye összegezve pedig a következő:

- A vállalati folyamatok során keletkezett adatok rögzítése

- A vállalati folyamatok során keletkezett adatok alapján meghatározott mérőszámok számolása és rögzítése

- A vállalat környezetében a vállalkozásra hatással lévő tevékenységek során létrejött adatok rögzítése

- Számviteli adatok rögzítése és riportálása a jogszabályban megfogalmazottak alapján

- Költségek nemenként, személyenként, kódonként való rögzítése és riportálása, elemzése

- Pénzügyi tevékenységekkel kapcsolatos adatok, információk, bizonylatok rögzítése, létrehozása

- Anyagfelhasználások rögzítése, fogyás jelentések készítése, elemzése

- A vállalkozás ügyfél és partner adatainak gyüjtése, rögzítése és szeparálása

- Termékfejlesztéssel kapcsolatos adatok gyüjtése, rögzítése, elemzése

- Marketinggel kapcsolatos tevékenységek adatainak rögzítése, elemzése

- Stratégiai (értékesítési, marketing, termelés, stb) tervek és tények rögzítése és elemzése

- Minőségirányítási rendszerrel kapcsolatos mérőszámok, adatok rögzítése és elemzése

- A vállalkozás teljesítmény értékeléséhez szükséges adatok gyűjtése, rögzítése és értékelése

Az összefoglalások alapján jól látható hogy jelentős különbség nincs a nagy és a kisszervezetek információ igényei között. A differencia abból adódik, hogy a nagy szervezeten belül a konkrét feladatokat, tevékenységeket és a munkafolyamatokat nagyban befolyásolja a vállalat mérete, a szervezet tagoltsága, valamint a vállalkozási tevékenység sajátosságai. Vagyis a nagyvállalat esetében a tagoltsága okozza a többlet információ igényét.

Kutatásom során vizsgálnom kellett, hogy az ERP rendszerek funkció kínálata mennyiben elégíti ki a gazdasági társaságok információs keresletét, vagyis az informatikai rendszer 
felépítése és funkciói általában mennyire felelnek meg a vállalat információs rendszerének és változások esetén mennyire gyorsan képesek a változást lereagálni.

\section{2. táblázat. A gazdasági társaság típusok és az ERP rendszer moduljainak kapcsolata}

\begin{tabular}{|c|c|c|c|}
\hline & Mikro vállalat & KKV & Nagyvállalat \\
\hline Pénzügy - számvitel & $\square$ & $\square$ & $\square$ \\
\hline Bér-és munkaügy & $x$ & $\square$ & $\square$ \\
\hline Tárgyi eszköz & $\square$ & $\square$ & $\nabla$ \\
\hline Kontrolling & $\square$ & $\square$ & $\square$ \\
\hline Termelés & $\nabla$ & $\nabla$ & $\nabla$ \\
\hline Raktárkészlet & $\square$ & $\square$ & $\square$ \\
\hline Beszerzés & $\square$ & $\square$ & $\square$ \\
\hline Értékesítés & $\nabla$ & $\nabla$ & $\square$ \\
\hline Disztribúció & $\square$ & $\square$ & $\nabla$ \\
\hline Ügyfélkapcsolat menedzsment & $x$ & $x$ & $\square$ \\
\hline Projektmenedzsment & $x$ & $x$ & $\square$ \\
\hline
\end{tabular}

Forrás: Saját szerkesztésủ táblázat

A 2. táblázat jól szemlélteti, hogy a gazdasági társaságok típusainak méretüktől függően a piacon kínált ERP rendszerek mely funkcióira van, és mely funkciókra nincs szükségük.

A szervezeti nagyság és tagoltság miatt a nagyvállalatoknak az ERP rendszerek által kínált összes funkcióra, modulra szükségük van, hogy hatékonyabbá tegyék folyamataikat és ezáltal a vállalatirányítását is. Egy adott ERP rendszer összes modulját maradéktalanul ki tudják használni, és mivel folyamataik eleve standardizáltak, így az informatikai rendszer bevezetése és a folyamatokhoz való igazítása nem okoz problémát. Ebben az esetben képes megvalósulni az informatikai és a vállalati folyamatok közötti szimbiózis. Technikai oldalról azonban, jelentős piaci változások esetén a rendszer átparaméterezése időigényes és erőforrásból is jelentős felhasználást igényel, éppen a szervezet nagysága és tagoltsága miatt. Ebből és az előzőekben leírtakból következik, hogy a nagyvállalatok a jelentős piaci változásokat terjedelmük miatt nem képesek rugalmasan és gyorsan lereagálni. Ugyan a szervezet egyes részei képesek az az új helyzethez alkalmazkodni, de ez önmagában kevés és a vállalat egészére kihatni nem képes.

KKV-k esetében az ERP kínálta modulok közül a projektmenedzsment és az ügyfélkapcsolat menedzsment az, amelyre ezek a kis szervezetek nem tartanak igényt. Ennek oka abban keresendő, hogy folyamataik úgy vannak felépítve, hogy mindegyikhez 
egy alkalmazott van rendelve, aki átfogja az egész folyamatot, ezért nincs szüksége a KKV-nak erre a két modulra. Továbbá azért sem tartanak igényt ezekre a modulokra, mert sem a projektek, sem a vevők kapcsán nem szükséges nagy adathalmazt kezelniük, azt más erre alkalmas kisebb, vagy standard alkalmazásban oldják meg. ${ }^{8}$ A szervezet méretei miatt nem minden alfunkciót használ ki az informatikai vállalatirányítási rendszerek moduljaiban, így már a rendszer telepítésekor jóval kevesebb funkciót kell felparaméterezni a megfelelő müködéshez. Ez azt is jelenti, hogy nagyobb piaci változások esetén a változásokhoz kapcsolódó átparaméterezések kevésbé idő és erőforrás igényesek, mint a nagyobb szervezetek esetében. Ebből következik, hogy egy kisebb méretü vállalkozás hamarabb képes alkalmazkodni a megváltozott piaci viszonyokhoz, mint nagyobb versenytársai.

A mikrovállalkozások elméletileg ugyanazokat az ERP rendszer modulokat használják, illetve nem használják, mint a KKV-k, de a gyakorlatban - véleményem és tapasztalataim alapján - jóval kevesebb funkciót telepítenek és paramétereznek fel, mint a KKV-k. A mikrovállalatok esetében egy alkalmazott több folyamatot is visz, ezért általában kihasználják az informatikai rendszer moduljainak hasonló alfunkcióit és ennek megfelelően telepítik az ERP rendszert. Ami ebben az esetben is azt jelenti, hogy kevesebb funkciót kell átparaméterezni piaci változások esetén, mint a nagy szervezetekben, vagy a KKV-k esetében.

Összegzésként elmondható, hogy a kisebb méretű szervezetek, gyorsabban és rugalmasabban reagálnak a piac és a gazdasági élet változásaira. Ebböl adódóan, ha ERP rendszert alkalmaznak folyamataik hatékonyabbá tételére, azok funkcióiból csak a számukra nélkülözhetetleneket telepítik és paraméterezik, így változások esetén rövid időn belül képesek az ERP rendszert is a megváltozott körülményekhez igazítani.

Nagy szervezetek esetében a szervezet nagysága miatt, lassabban reagál a változásokra, és mivel az alkalmazott ERP rendszerek is teljes funkcionalitásukban támogatják a szervezet munkafolyamatit, így az informatikai rendszer is nehezebben igazodik a megváltozott viszonyokhoz. A nagyvállalat egyes részegységei ugyan képesek gyorsabban lereagálni a gazdasági élet átalakulását, az nem hat ki az egész szervezetre, tagoltsága és mérete miatt.

\footnotetext{
${ }^{8}$ Ilyen alkalmazások az Excel vagy az Access, de elterjedtebb az Excel kis vállalkozásoknál, mint nyilvántartó és a nyomon követhetőséget biztosító informatikai eszköz.
} 
Hipotéziseim tekintetében a szakirodalmi és a saját kutatásaim eredményei alapján a következő megállapításokat teszem:

Első hipotézisem igazolására, miszerint „A folyamatos piaci változás követéséhez a jelenlegi verseny eszköztár nem elég adaptív.” sem a szakirodalmi sem a saját vizsgálat során nem találtam meggyőző bizonyítékokat, sem annak megcáfolására, így ezt a hipotézisemet a további kutatásban nem vizsgálom.

Az a felvetésem, hogy „A gazdasági élet szereplöinek mérete, formái és folyamatai meghatározzák rugalmasságukat az üzleti élet változásaival szemben.” saját kutatásaim alapján igazolást nyert, a további vizsgálataim során ezt a hipotézisemet ki fogom terjeszteni a folyamatokat befolyásoló tényezők vizsgálatára.

Az a hipotézisem, hogy „A gazdasági élet szereplöinek mérete, formái és folyamatai befolyásolják a használt ERP rendszer alkalmazkodását a megváltozott piaci helyzetekhez." saját kutatásaim alapján igazolást nyert, így ezt a felvetésemet a további vizsgálataim során kiterjesztem az adaptív ERP rendszert befolyásoló tényezők vizsgálatára.

Véleményem szerint tehát a kutatásom elején megfogalmazott három hipotézisemből kettő igazolást nyert, egyet viszont sem igazolni, sem megcáfolni hitelt érdemlően nem tudtam, így azt a további vizsgálódásból kizártam.

Úgy vélem, hogy az ERP rendszerek alkalmazkodási képességét azért befolyásolják a vállalat folyamatai, vagy mérete, mert ez határozza meg, hogy az ERP rendszer hány modulját telepítik le és mennyi funkciót paramétereznek fel a telepítés során. Ha túl sok funkciót paramétereznek fel és túl sok modult telepítenek, annak az hátránya, hogy egyegy nagyobb piaci, gazdasági változás esetén ezeket a beállításokat egyenként kell átállítani, ami jelentős időt vesz igénybe, ami üzleti hátrányt is okozhat az ERP rendszert használó szervezet számára.

\section{ÖSSZEFOGLALÁS}

Az információ az élet minden területén fontos szerepet játszik, nincs ez másképpen a gazdasági életben sem, mert tudjuk, hogy az információ és a tudás érték és hatalom, nincsenek ezzel másképpen a gazdasági élet szereplöi sem. Információra és tudásra van szükségük ahhoz, hogy piaci helyzetüket megszilárdítsák, hogy versenyelőnyhöz jussanak, vagy éppen megszorongassák versenytársaikat, ehhez azonban nem elég csak a vállalat belső tevékenységre, folyamatokra koncentrálni, terméket fejleszteni, szükséges a vállalat 
környezetében történő események gyüjtése és dokumentálása is, de még a belső történések feljegyzése is nélkülözhetetlen. Ezeket az adathalmazokat olyan megbízható helyen kell tárolni, amely képes az összes történést egy helyen elhelyezni és biztosítani, hogy egy időben több érdekelt is képes legyen látni és használni azokat.

Erre az igényre született meg válaszul az ERP rendszer, amely azonban önmagában nem képes mindazt biztosítani, amire a vállalatnak a müködéshez a vezetőségnek pedig a döntéshozatalhoz szüksége van. Az ERP rendszer csak támogatni tudja egy vállalkozás irányítási rendszerét, amely a gazdasági társaság munkafolyamatainak összességét szabályozza és ellenőrzi, és amely megfelel a hatályos jogszabályok előírásainak. Vagyis a vállalkozásoknak szükségük van egy vállalatirányítási és az azt támogató informatikai rendszerre is ahhoz, hogy müködésük hatékonysága növekedjen, és sikeresen végre tudják hajtani vállalati stratégiájuk lépéseit.

Kutatásom során arra fókuszálok, hogy a vállalati informatikai rendszerek mennyire képesek lekövetni a piac és a gazdaság változásait anélkül, hogy nagyobb költség és idő ráfordításra lenne szükség. Vizsgálataim elsősorban arra koncentráltak, hogy milyen igényeik vannak a gazdasági élet szereplőinek és mit kínálnak a piacon lévő ERP rendszerek. Úgy vélem a keresleti és kínálati oldalt ebben az esetben is össze kell egyeztetni, hiszen a kínálati oldalon feltűnő hiányosságok és a keresleti oldalon jelentkező túlzott elvárások befolyásolhatják a használt ERP rendszer alkalmazkodóképességét. Ez különösen abban mutatkozhat meg, hogy egy-egy változást az informatikai rendszer csak lassan képes lereagálni, ami a felhasználónak, nem csak anyagi, de üzleti károkat is okozhat.

A kutatás során felmerült annak lehetősége, hogy a gazdasági társaság mérete is befolyásolja az ERP rendszerek adaptivitását, hiszen egy nagy szervezet tagolt és egy-egy munkafolyamatot több alkalmazott végez el, ezért is fontos, hogy folyamatleírásokkal segítsék a vállalat müködését. Ebböl következik az is, hogy ha a szervezet az ERP rendszer több funkcióját használja egyszerre, akkor változások esetén számos funkció átparaméterezése válik szükségessé, ami munka- és időigényes feladat. Egy kis szervezet esetében a folyamatok jóval egyszerübbek, ezért az ERP rendszerben is kevesebb funkciót használnak, mint nagyobb társaik, így a piac változásait is gyorsabban képesek lekövetni.

A kutatás jelen szakaszában a vizsgálatot elméleti síkon folytattam le és szekunder információkat, a szakirodalomban megjelent eredményeket, információkat értelmeztem újra. Egy háromtagú hipotézis-csoporttal indultam el, amelyek az ERP rendszer 
adaptivitására, illetve a szervezet mérete és az informatikai rendszer alkalmazkodóképességének kapcsolatára kereste a választ. A három hipotézisemből egyet a vizsgálat eredményei tükrében el kellett vetnem és a további vizsgálódásból ki kellett zárnom, hiszen egyértelműen sem igazolni, sem megcáfolni nem tudtam a felvetést.

Vizsgálataim eredményei alapján biztosan állíthatom, hogy a gazdasági társaság mérete és az általuk használt ERP rendszer alkalmazkodóképessége, adaptivitási foka között szoros összefüggés van, ahogy a szervezetek rugalmasságát is befolyásolja méretük. Minél nagyobb egy szervezet annál több és bonyolultabb folyamatot kell kezelnie, így mire egy változás végig fut az összes folyamaton, az sok időt vesz igénybe, azaz a teljes rendszer lomhábban reagál, mint egy-egy részterülete.

A gazdasági élet szereplőinek szükségük van rendezett és rendszerezett folyamatokra és a történések dokumentálására, ehhez pedig a legjobb eszköz a kontrolling, a számvitel és a minőségirányítás elöírásai alapján kialakított vállalatirányítási rendszer és az azt segítő informatikai rendszer megléte és használata. Azt azonban mindenképpen szem előtt kell tartani, hogy a kialakított rendszer csak akkor lesz adaptívnak tekinthető, csak akkor képes rugalmasan alkalmazkodni a környezeti változásokhoz, ha már a megtervezésekor átgondolja a vállalkozás az összes folyamatát, ésszerűsíti azokat és alkalmazottait felkészíti a várható változásokra. Ezek nélkül a rendszer nem fog megfelelően működni, ahogy az őt segítő informatikai rendszer sem, ez pedig hosszútávon, a várt előny helyett hátrányt fog okozni a gazdasági társaság számára.

\section{FELHASZNÁLT IRODALOM}

Angyal Ádám (2001). Vállalati Kormányzás, Aula kiadó Budapest Barry Elliott - Jamie Elliott (2010). Financial Accounting and Reporting, Prentice Hall Bács Zoltán - Várallyai László (2004). Ügyviteli ismeretek, Campus kiadó Debrecen Bojtos Júlia (2004). Controlling értelmező szótár IFUA Horváth \& Partners, Vezetési és Informatikai Tanácsadó Kft

Bögel György - Salamonné Huszti Anna (1998). Vállalatvezetés felsőfokon, Kossuth Kiadó Budapest

Dankó László (2000). Értékesítés Pro Marketing. http://ebookz.hu/ebook.php?azon=a7aef8 Dobay Péter (1997). Vállalatinformáció menedzsment, Nemzeti Tankönyvkiadó Budapest

Dr. Schwarczenberger Istvánné (2008). A versenyképes vállalatirányítás http://dtt.bmsinformatika.hu/dspace/handle/BMS/55

Dr. Holyinka Péter. Az információs rendszerek rövid fejlődés története http://www.erport.hu/index.php?id=44

Erdős Ferenc (2008). A KKV-k informatikai beruházásai és azok megtérülési lehetőségei, Magyarországon Doktori értekezés 
Horváth Péter (1993). Controlling a sikeres vezetés eszköze, Közgazdasági és Jogi könyvkiadó Budapest

Irányítás és Informatika folyóirat 2000. évi számai

José A., Hernandez Jim Keogh, Franklin F. Martinez (2007). SAP R/3 Kézikönyv; Panem Könyvkiadó Kft.

Kacsukné Dr. Bruckner Lívia - Kiss Tamás (2007). Bevezetés az üzleti informatikába

Kardos Barbara - Szatnó Imre - Veress Attila (2007). A vezetői számvitel alapjai, Saldo Zrt. Budapest

Kelemenné Ternai Katalin (2003). Az ERP rendszerek metamorfózisa In: Vezetéstudomány 2003. július - augusztus

Kondorosi Ferencné Dr. Ph.D (2004). Kiegészítés és Példatár a vezetői számvitel és elemzés alapjaihoz

Orbán Anna (2006). Vezetői információs rendszerek a közigazgatásban, BCE Budapest

Szervezési és Vezetési ismeretek folyóirat 2002. évi számai

Thomas F. Wallace - Michael H. Kremzar (2006). ERP - Vállalatirányítási rendszerek, HVG Kiadó Rt Budapest

http://www.piksys.hu

http://www.microsoft.com 